With this issue of The Forum, we are introducing a new section featuring an exemplary senior project by a recent graduate. A requirement of every Cal Poly graduate with a B. A. in History, this two-quarter, culminating experience permits advanced students to "do history" in ways that more closely reflect their own intellectual interests and passions. The objective of senior project is to produce an essay or creative project that makes optimal use of the knowledge and skills advanced history students have acquired during their academic career. Combining the examination of primary sources with secondary interpretations, the completed project should reflect extensive research, astute analysis, and careful presentation. 


\section{CONTIBUTOR BIO}

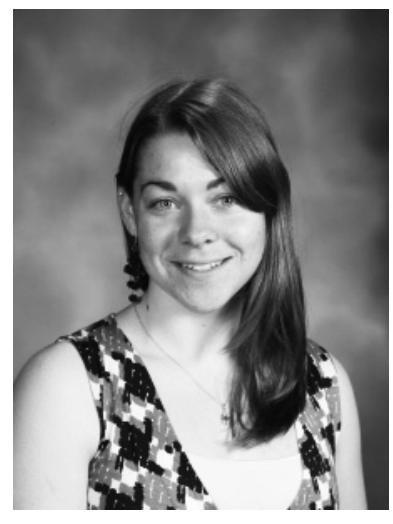

ELIZABETH METELAK graduated summa cum laude from Cal Poly with a Bachelor of Arts in History and a minor in Latin American Studies in 2012. She currently teaches pre-modern world history to 9th graders in inner-city New Haven, Connecticut through Teach for America and Achievement First. While she sometimes misses San Luis Obispo sunshine, she loves New Haven's abundance of Thai food and the ethnic, linguistic, and cultural diversity of the city. When not working with her students, she continues to pursue her interests in writing, Eastern European history, and cycling. 


\title{
CONSTRUCTING IDENTITY IN A POST-WAR WORLD
}

Elizabeth Metelak

\begin{abstract}
"The Council of Lithuania, as the sole representative of the Lithuanian nation, based on the recognized right to national self-determination, and on the Vilnius Conference's resolution of September 18-23, 1917, proclaims the restoration of the independent state of Lithuania, founded on democratic principles, with its capital in Vilnius and declares the termination of all state ties which formerly bound this State to other nations."
\end{abstract}

On February 16, 1918, the Tarbya, or Council of Lithuania, signed the above Act of Independence of Lithuania, declaring the restoration of Lithuania as an independent state after centuries under Prussian and Russian imperial rule, and setting off more than a decade of regional conflict concerning what this could and should mean for Lithuanians and their neighbors. Although occupying German forces initially suppressed this document, ensuring a pointed lack of immediate results, the tides of war gradually bestowed the Tarbyas words with more than mere symbolism. Even before Germany formally surrendered, the

\footnotetext{
${ }^{1}$ Lietvos Tarbya, "Lietuvos Nepriklausomybè Aktas" in "Historical Lithuania," Vilnews.com, last modified 14
} 
Lithuanian Constituent Assembly had authored a provisional constitution, and Lithuanians celebrated Armistice Day less than two weeks later with the establishment of the first government of an independent republic of Lithuania.

Relying on the democratic principles espoused by the victors of World War One and the promises of Wilson's Fourteen Points, Lithuanian leaders forged ahead on the path to self-determination, immersing themselves in the tasks of designing and implementing a functioning government that corresponded to their understandings and expectations of a Lithuanian state. Within no time at all however, these leaders found their plans and definitions challenged on nearly every front. Within Lithuania itself, political parties old and new, from Christian Democrats and Populists to Social Democrats, Communists, and National Unionists, each struggled to ensure that their agenda took precedence in the newly formed state. Outside the government, Lithuania's various ethnic, religious, class, and occupational groups engaged in their own conversations about independence and the new Lithuania.

External interpretations and agendas for the Lithuanian region also developed in the massive international realignment that characterized the end of the war. Despite the Allied victors agreement on the need for self-determination in post-war Europe from an ideological standpoint, many powers delayed official recognition of the new Lithuanian state as unimportant, asserting a need for additional evidence prior to considering the case. They demanded that the Lithuanian government prove in some way that they in fact held any sort of historic or ethnographic claim to lands and people contained within the borders of the new state. The fledgling League of Nations, suddenly responsible for determining the status of would-be states, excluded Lithuania from membership on the grounds that the United States already refused to recognize Lithuania. The United States, at the time embroiled in a frenzy of anti-communist hysteria known as the Red Scare, justified its refusal as an unwillingness to acknowledge the new Communist government of Russia and the loss of Russia's imperial prerogatives to Lithuanian lands.

In this period of uncertainty, several of Lithuania's neighbors saw the opportunity to make their own claims concerning the nature of the Lithuanian state. The Red Army invaded in November 1918, seeking to reclaim lands once considered part of the Russian Empire. A group of German military adventurers also took up arms against Lithuania in hopes of preserving German influence in the region. Hot on their heels, newly independent Poland swept in from the 
southeast as part of a grand offensive against the Russian army. In the process, they unashamedly occupied Lithuania’s capital at Vilna, and claimed over a third of Lithuanian territory as its own.

Given the lasting impact of this period on future political developments and diplomatic relationships, the dearth of academic analysis on this region proves particularly disappointing and problematic. This partially stems from fifty years of Soviet occupation that limited scholarly access to materials concerning Lithuania, and also discouraged public discussions and displays of nationalism within Lithuania itself. Most studies that even mention the formation of the Lithuanian state do so briefly or within an analysis of the Baltic States as a group. ${ }^{2}$ Moreover, authors tend to frame the 1910's and 1920's in light of the 1990 's round of independence, a mere blip within the more general story of occupation and oppression finally shaken off in 1991. Not until recent years have a few more-informed studies of this topic emerged, mostly by Lithuanian citizens or expatriates, indicating continued lack of interest toward the region among the majority of scholars (and the world at large).

In Alfred Senn's exploration of the Polish-Lithuanian conflict and its relationship to Western powers, he blames the situation's lack of resolution on the ignorance of the Western Allies concerning Eastern Europe's nationalist trends and their inability to engage Poland and Lithuania as two sovereign nations. ${ }^{3}$ For Senn, this combination of condescension and incomprehension drastically crippled the League of Nations' and Entente Powers' abilities to act decisively or effectively in Lithuania, to the detriment of the young Lithuanian state. Unfortunately, Senn refuses to engage the Polish perspective in his analysis because he perceived it as less meaningful than Lithuania's. Meanwhile, Zigmantas Kiaupa eschews any detailed analysis of the League, and focuses instead on the military conflicts that plagued Lithuania's early years, and their influence in shaping the political structure of the state. ${ }^{4}$ Both these studies suffer however, from the innate nationalist sentiments of their own authors, adopting Lithuania's historic enemies as their own and failing to address conflicting viewpoints objectively. This paper seeks to remedy these deficiencies by creating a more

\footnotetext{
${ }^{2}$ For example, John Hiden and Patrick Salmon, The Baltic Nations and Europe: Estonia, Latvia, and Lithuania in the Twentieth Century, (London: Longman, 1991).

${ }^{3}$ Alfred Erich Senn, The Great Powers, Lithuania, and the Vilna Question: 1920-1928, (Leiden: E.J. Brill, 1966), ix.

${ }^{4}$ Zigmantas Kiaupa, The History of Lithuania, (Lithuania: baltos lankos, 2002), 240-258.
} 
complete and multi-dimensional analysis concerning the formative years of the first Lithuanian Republic. Moreover, it will attempt to draw further conclusions concerning the creation and interpretation of Lithuanian national identity as a multi-directional discourse between Lithuania and other entities.

Over the first years of the new state's existence, Lithuanians expelled the Russian and German troops, and held off further advances by the Poles, while presenting and re-presenting their case for existence and certain prerogatives to the League of Nations and individual national governments. Set upon on all sides, and desperate for acceptance as a legitimate European state, the Lithuanians compiled mountains of historic, ethnographic, and linguistic evidence to support their right to exist and to claim certain territories. Given the intensely nationalistic rhetoric surrounding nearly every aspect of the First World War, it comes as no surprise that this evidence would ultimately outline Lithuania's own equally intense brand of national identity. More importantly, however, these interactions created a vast international dialogue concerning the nature and identity of the Lithuanian state that reached far beyond Lithuania's disputed borders. This dialogue engages a wide variety of speakers in complex issues of democracy, national identity, and self-determination, both within the Lithuanian state and without. Ultimately, these players have as much, if not more, impact on the nature of the Lithuanian State as the Lithuanians themselves, and it is this dialogue that truly shapes the strength and character of Lithuania's national identity.

While a significant number of new nations, states, and combinations thereof, emerged from the chaos of the First World War, and the international community devoted significant time and energy to each case, this paper restricts itself to issues of Lithuanian national identity and statehood, except where other cases (such as Poland) play a direct role in Lithuanian development. This approach does not seek to belittle the efforts of other groups or organizations in this process, but rather to focus on the methods, successes, and failures of one people whose story and importance find themselves frequently overlooked in studies of the region and period, but still hold vital historical significance for anyone concerned with issues of national identity in the formation of states.

In its interpretation on nationalism as a multi-directional discourse, this paper relies on people and documents from a wide range of sources, which have been incorporated as much as possible in the scope of this work. Unfortunately the author's own language limitations have heavily impacted the types of sources 
consulted in the course of this research. Thus, while a few documents have been translated from Lithuanian specifically for this paper, the majority of sources are those originally published in English - diplomatic correspondence, US newspaper articles, US Senate, and League of Nations documentation - or those translated to English by Lithuanians and Lithuanian Americans for the benefit of the international community. While these circumstances might neglect the voice of the Lithuanian peasantry particularly, certain travelogues serve as a vehicle for some peasant sentiments concerning Lithuania's place in the world at large. ${ }^{5}$ Moreover, this approach demonstrates the intricacies of the dialogue surrounding national identity and the vast international scale within which these conversations occur.

Due to the complexities of war and ever-shifting borders, as well as conflicting claims over Lithuanian territory and identity, many people, places, and organizations appear under different names in different accounts. In striving for historical accuracy, this paper incorporates the most relevant terminology in each situation, dependent on the time period and the term used by each particular document. Thus Lithuania's present capital, Vilnius, may appear as Wilno (Polish), Vilnius (Lithuanian), or Vilna (international), and certain people's names may appear in their Polish or Lithuanian renditions (for example) depending on the context. These distinctions are not intended to confuse, but to realistically reflect the language of the period and reiterate the complexities inherent to the formation of national identity within Lithuania.

\section{Young Nationalism: Infancy to Adolescence}

Modern Lithuanian nationalism traces its roots to Lithuanians' reactions against growing oppression in the second half of the nineteenth century. While regional uprisings and agitations, supplemented by differences in language and culture, fostered a level of national consciousness in many parts of Eastern Europe, Lithuanian nationalism found its growth stunted by the region's historic union with Poland, the Polonization of many Lithuanian elites, as well as the region's absorption into the Russian Empire in $1795 .{ }^{6}$ Not until Tsar Alexander II officially abolished serfdom throughout the empire in 1861 did

\footnotetext{
${ }^{5}$ See Peter Saurusaitis, Thirty Days in Lithuania, (Illinois: Call Printing Company, 1920), for example.

${ }^{6}$ Alfred Senn, The Emergence of Modern Lithuania, (New York: Columbia University Press, 1959), 4.
} 
nationalist sentiment in Lithuania truly develop a life of its own. ${ }^{7}$ 1861-1862 saw widespread demonstrations by Lithuanian peasants angry at delays in emancipation, followed by a joint Polish-Lithuanian uprising in 1863. The tsar's harsh dealings with the Uprising led to a general decline in the power of the Lithuanian gentry, who suffered land confiscations and heavy fines for their involvement. Alexander II and his son's ensuing policies of Russification restricted the use of Lithuanian language, the practicing of Catholicism, and otherwise limited Lithuanian politics and culture.

The same agitations that set Lithuanians at odds with their Russian masters ultimately severed ties with their Polish brothers-in-arms as well. The paths of the two peoples converged in the fourteenth century through the marriage of their two sovereigns, the Lithuanian Grand Duke Jagiela and the Polish queen Jadwiga, to form a kingdom that stretched from the Baltic to the Black Sea. Lithuanians claim that in 1569 , the Polish coerced Lithuania into a formal union signed at Lublin that infringed upon their status as a sovereign people. ${ }^{8}$ The Poles conversely claim that this union sprang from the mutual strengthening of their ties and that it brought unity and culture to the Lithuanians. ${ }^{9}$ Over time, much of the Lithuanian gentry adopted Polish language and culture, leaving Lithuanian peasants to preserve their own language and traditions, but inadvertently blurring the lines between the two cultures more than replacing either. Authors like the poet Adam Mickiewicz wrote proudly of the Lithuanian fatherland, but referred to the Polish Litwa rather than the Lithuanian Lietuva. ${ }^{10}$ Even in Vilna, Lithuania's historic capital, one could hear far more Polish or even Yiddish spoken in the streets than Lithuanian, making the city a source of contention until the end of the Second World War.

Over time, a small Lithuanian intelligentsia emerged, striving to reestablish the language and culture that had fallen out of use among the educated under Polish influence. The region found itself divided, at times so much that one brother might identify as Polish while another declared himself Lithuanian. The 1863 Uprising brought these tensions to the forefront as Polish and Lithuanian

${ }^{7}$ Kiaupa, 183-188, Thomas Balkelis, The Making of Modern Lithuania, (London: Routledge, 2009), 10

8 "A Historical Survey of Lithuania, The Lithuanian-Polish Dispute, (London: Eyre and Spottiswoode, Ltd., 1921), 5.

'Poland and Lithuania: The Question of Wilno, edited by the Society “Straż Kresowa," (Warsaw: IMPR Galewski and Dau, 1921), 7-8.

${ }^{10}$ Mickiewicz, Adam, Pan Tadeusz, trans. by Leonard Kress, HarrowGate Press, 2006), 5. 
aims for the rebellion diverged drastically. Polish leaders spoke of Lithuania as a territory of Poland, while many Lithuanian leaders viewed the uprising as an opportunity to pull away from the Poles and restore Lithuanian autonomy. These conflicting viewpoints led to irreparable divisions between the Polish and Lithuanian nobilities in their plans for the uprising and the future of the region. Such radically different interpretations of the region's history and culture sparked massive conflict that continued unabated and unresolved despite larger conflicts with the Russian and German Empires and even as younger generations of Poles and Lithuanians began to develop new forms of nationalism within their respective cultures. ${ }^{11}$

Thomas Balkelis traces the origins of this new Lithuanian nationalism to an emerging intelligentsia born from the imperial Russian education system and subsequent exposure to Russian intellectual culture. ${ }^{12}$ As increasing numbers of Lithuanian students graduated from Russian universities and began seeking employment, many of them found work as doctors, lawyers, and teachers, and made their way into Lithuania’s Polish and Jewish dominated cities for the first time. In Balkelis' estimation, cities like Mariampol and Vilna became centers of patriotic activity, while other members of the intelligentsia assimilated into Russian culture or else took refuge abroad. ${ }^{13}$ These increasingly secular urban intellectuals orchestrated the creation of illegal patriotic publications like Aušra (Dawn) and Varpas (The Bell) that allowed them to voice their nationalist sentiments and political agendas in the now-banned Lithuanian language. This defiance however, required time to bridge the gap between the city and the country, between the wealthy and the peasants. An urban middle class grew slowly and painfully as professionals from peasant backgrounds struggled to adjust their way of life. ${ }^{14}$ By the turn of the century, this group, while by no means cohesive, had somewhat consolidated political leadership within a covert Lithuanian nationalist movement. ${ }^{15}$ Unfortunately, this movement's discussions and actions remained disconnected from society at large.

Lithuanians only began to remedy this breach with the outbreak of revolution across the Russian Empire in 1905. Massive unrest within the peasant

${ }^{11}$ Kiaupa, 187-188.

${ }^{12}$ Balkelis, 12.

${ }^{13}$ Balkelis, 24.

${ }^{14}$ Balkelis, 38-39.

${ }^{15}$ For a more in-depth discussion of this period, see Thomas Balkelis' detailed analysis of the Lithuanian intelligentsia in The Making of Modern Lithuania. 
and labor populations ignited a fire of political unrest at every level of society within the imperial context. Emboldened by the actions of the lower classes, underground political leaders throughout the land also arose in opposition to the tsar's autocratic government with calls for representation and democracy. Lithuania proved no exception to this case. Workers' strikes and agricultural demonstrations demanded social equities long denied to the lower classes, jolting Lithuanians into action on every level while also providing an audience with which political leaders could share their agendas. While the Lithuanian intelligentsia welcomed such opportunities to promote national consciousness, they proved tremendously unprepared to harness the energies of the peasants and workers. ${ }^{16}$ Hopelessly divided amongst themselves, various political parties broached numerous resolutions designed to end the conflict and secure a permanent peace, but achieved little in the way of unifying the movement.

Despite the lack of political unity in this moment, a 1919 publication recalls that in 1905, "the national consciousness in Lithuania was so strong and widespread, throughout the land that it was possible to call a convention from all parts of Lithuania." ${ }^{17}$ As Lithuanians gathered for the convention then known as the All-Lithuanian Assembly, now referenced as the Grand Seimas, the nationalist movement began to coalesce into something far greater than fragmented pockets of political elites. ${ }^{18}$ The congress met in late November, with roughly 2,000 delegates covering topics from autonomy to education to agriculture, and eventually settling on a rather ambitions program for the unification and improvement of Lithuanian society. This event also ushered a greater number of common people into the political arena than ever before, forming a mass movement where only elites had agitated formerly. This drastic shift in participation found the people of Lithuania increasingly invested in the formation of a Lithuanian nation and brought them one step closer to a coherent national identity.

Although the Revolution of 1905 petered out without truly democratizing the empire, the establishment of the Duma, an empire-wide representative assembly announced by Nicholas II's October Manifesto, sparked significant interest within Lithuania. The same concessions granted Lithuanians increased

\footnotetext{
${ }^{16}$ Balkelis, 38.

${ }^{17}$ Kunigas Antanas Jusaitis, "The History of the Lithuanian Nation and its Present National Aspirations," (Philadelphia: The Lithuanian Catholic Truth Society, 1919), 79.

${ }^{18}$ Balkelis, 59-60.
} 
political freedoms, including the ability to publish in their native language for the first time in over forty years. These developments ushered in waves of new publications, cultural, political, and otherwise, in the Lithuanian language. Despite the Duma's repeated dissolutions, Lithuanians actively engaged in that forum as long as they could, before ultimately returning their focus to Lithuanian people and lands. Lithuanian cultural work became the defining element of these years, leading to the development and refinement of a national culture long before the movement could propose the idea of an independent Lithuanian state. Music, dress, and writing flourished as distinct costumes and customs came to stand as emblems of the Lithuanian people, and spread through the cities like fire. This cultural coherency left Lithuania far more united than many of its nearest neighbors, eagerly awaiting the opportunities that war would soon bring.

\section{Growing Pains: War and Acceleration}

The coming of world war rapidly accelerated the development of national identity in Lithuania. Most scholars agree that despite (or perhaps because of) their own nationalist sentiments, when Germany declared war on Russia on August 1, 1914, Lithuanians rallied enthusiastically to the tsar's cause. ${ }^{19}$ This enthusiasm, however, appears much more opportunistic than heartfelt; leaders in Vilna almost immediately submitted a declaration to the Russian government in favor of combining the two Lithuanian jurisdictions and granting them autonomous status within the empire. Lithuanian political leaders hoped that the context of war might allow them to gain political concessions from the empire that might have otherwise gone unaddressed. ${ }^{20}$ Their "Amber Declaration" met with a rapid, angry dismissal by the Russian government, but such sentiments only gained momentum in Lithuania as the war dragged on. ${ }^{21}$

As these conversations unfolded, Russian and German hostilities quickly transformed Lithuania into a warzone. Much of the early fighting during the First World War took place not in France and Belgium, as the focus of many

${ }^{19}$ Balkelis, The Making of Modern Lithuania, 105. Senn, The Emergence of Modern Lithuania, 18. Kiaupa, The History of Lithuania, 227. Stanley Page, The Formation of the Baltic States a Study of the Effects of Great Power Politics upon the Emergence of Lithuania, Latvia, and Estonia, (Cambridge: Harvard University Press, 1959), 27. This was also not an unusual phenomenon across Europe in the early months of the war.

${ }^{20}$ Senn, Emergence, 18.

${ }^{21}$ Balkelis, Making, 105. 
retellings seems to indicate, but in the east, where the Russian Empire and the Central Powers swept back and forth across Poland and Lithuania in their quests for supremacy. For those remaining in the region, the "terrible destruction caused by war" ensured that impoverishment, starvation, and displacement became the norm. ${ }^{22}$ Forests and vegetation disappeared in the wake of powerful new artillery raids, while cities and farms burned to the ground with an alarming frequency. ${ }^{23}$ Compounding this distress, many maps at this time, and consequently early relief efforts, categorized Lithuania as Northern Poland, assuming that Polish relief agencies would seek to alleviate the suffering of this region as a matter of course. Unsurprisingly, Polish relief agencies already struggling to address the needs of Polish war victims had little ability or desire to stretch their resources any thinner for non-Poles (especially not their rivals in Lithuania), leaving Lithuanians in a desperate state. ${ }^{24}$

The coming of the German occupation quickly multiplied the intensity of suffering for the Lithuanian people, but this shift in power also ushered in new opportunities and risks for Lithuanians. By mid-1915, Germany had taken all of Lithuania, on into Latvia and Russia, forcing Russian officials and hundreds of thousands of refugees to flee deep into Russian territory. The German occupational government that replaced these officials proved exceedingly harsh, bringing inflation, a new currency, and compulsory labor to the already devastated land. ${ }^{25}$ Though bitterly oppressive, the occupation led Lithuanians to feel increasingly empowered to act on their own behalf, able to shape Germany's perceptions and administration of the region in ways that the Russian Empire had long prevented. Stanley Page elaborates on this trade-off in The Formation of the Baltic States, as he unravels the German thought process behind actions concerning the Eastern Front. By late 1916 and early 1917, Germany's position in the war looked rather tenuous. Hoping to recruit desperately-needed soldiers from their newly conquered territories, German leaders proclaimed the Kingdom of Poland an autonomous region within German jurisdiction, allowing the Poles a level of local authority that had long been denied provided that they supplied soldiers for the German army. ${ }^{26}$ Such a move however, posed

\footnotetext{
22 “Distress in Lithuania," New York Times, (Aug 12, 1915), 3.

${ }^{23}$ Ibid., 3.

${ }^{24}$ Ibid., 1.

${ }^{25}$ Kiaupa, 230.

${ }^{26}$ Page, 32.
} 
numerous risks to the Germans, namely that encouraging Polish nationalism significantly weakened Germany's grip on the region. Page believes that the Germans' only logical means to discourage nationalistic agitation in Poland lay in simultaneously promoting Lithuanian nationalism, which, due to the aforementioned disputes, frequently manifested itself as anti-Polish. ${ }^{27}$ Although they refrained from granting Lithuania autonomous standing as well, this strategy placed the two groups at odds with one another and distracted Lithuanians from formulating strong nationalist ideas or thoughts of independence.

While the decision to encourage two opposing nationalisms may have sprung from Germany's dire need to recruit able-bodied men for the front lines, German leadership seems to have significantly underestimated the strength and will of both movements in their calculations. Far from keeping one another in check, the leeway granted by the German strategy quickly transformed into the justification for subsequent demands for even greater levels of autonomy within Lithuania. Meanwhile, Russia's political turmoil began to take precedence over its war effort and its leaders began considering a separate peace with Germany. This dialogue centered primarily on the question of the German-occupied border regions, leading Lithuanians to fear immense losses of land and authority to the Poles in any settlement that might be reached. Poland had already (albeit prematurely) announced their annexation of Lithuania on May 24, 1917, spurring Lithuanians to cooperate with the Germans far more than they had ever intended. ${ }^{28}$ Lithuanians hoped that this cooperation would convince Germany to protect the integrity of Lithuania's borders from unwelcome Polish incursions. In reality, German concessions stemmed far more from their own agendas than any real concern for the Lithuanians.

Attempts to define Lithuanian borders and identity faced further obstacles when the Bolsheviks rose to power in Russia in October of 1917. Seeking to remove themselves from the war as quickly as possible with as little loss of territory as it could negotiate, Russia's Communist Party entered deliberations with the Germans at Brest-Litovsk. Through this process, the Bolsheviks clearly demonstrated that they possessed no desire to relinquish any of the territories belonging to the former Russian Empire. Alfred Senn notes that the Bolsheviks almost immediately established a Commissariat of Lithuanian Affairs and began

\footnotetext{
${ }^{27}$ Page, 32.

${ }^{28}$ Kiaupa, 235.
} 
suppressing nationalist agitation among Lithuanian refugees and refugee organizations based in Moscow and Petrograd. ${ }^{29}$ Moreover, neither the Bolsheviks nor the Germans permitted Lithuanians to join the delegations sent to the peace talks, forcing them to agree to German authority and the restriction of all but the most basic cultural autonomy in return for guarantees that Lithuania would remain intact and separate from Poland. ${ }^{30}$ While one nationalist finagled his way to the talks as an advisor to the Ukrainian delegation, the Lithuanians could do little to directly influence the nature of the discussion. ${ }^{31}$ They continued to meet with representatives of the German government to curry favor and gain more favorable terms for Lithuania, but their hands remained effectively tied throughout the conversation. This relative impotence proved short-lived, however, when continued military aggression forced the Bolsheviks to drop all demands and sign the Treaty of Brest Litovsk in early 1918, relinquishing their claims to all of its now German-occupied territories. Free from the uncertainties of the peace talks, Lithuanians immediately renewed their efforts to gain whatever autonomy the Germans would grant.

Even as they agitated within the parameters of German authority, Lithuanians began seeing the possibility of a truly independent Lithuania rising from the ashes of war. In January of 1918, the Lietuvos Aidas (Echo of Lithuania), a four page daily sponsored by the Tarbya, published several articles that testify to Lithuanians' strong nationalist sentiments and reflect the development of Lithuanian's hopes for the future. On New Year's Day, 1918, a second-page article recalled the 1905 Revolution and the Seimas that culminated in Lithuania's first claim of political autonomy within the Russian Empire. ${ }^{32}$ The author hearkens back to what he considers Lithuania's "first public protest" of its status, lauding the fire and passion of the Seimas, which he likens to a volcano of agitation in which the Lithuanian people finally voiced their determination to reclaim their long-lost political autonomy. ${ }^{33}$ The article pointedly credits the Seimas with having "convinced [the Lithuanians] that it [was] time to take

${ }^{29}$ Alfred Senn, Emergence, 29.

${ }^{30}$ Ibid., 29-32.

${ }^{31}$ Ibid., 31.

32 "Atsiminimai ir ịspūdžiai iš Didžiojo Vilniaus Seimos" (Remembrances and Impressions of The Great Seimas of Vilnius), Lietuvos Aidas, trans. Kristina Petruitytė, January 1, 1918, \#1(49), p. 2-3. http://www.epaveldas.lt/vbspi/biRecord.do?biExemplarId=66475

${ }^{33}$ Ibid., 2. 
actions and show that Lithuania [had] a right to seek its freedom.."34 By underscoring the similarities between Lithuania's situation in 1905 and 1918, the author indicates an avid hope to revive these sentiments within the Lithuanian population and reawaken a "real desire to walk the country out of misery." ${ }^{35}$

Just four days later, the front page of the Lietuvos Aidas declared to all of Lithuania that " $[\mathrm{an}]$ independent and democratically organized country with ethnological boundaries [was] needed" for Lithuanians to continue developing as a people. ${ }^{36}$ The article referenced a 1917 conference in Vilnius in which two hundred and twenty-two delegates had secured a general consensus to that effect and reiterated their desire for independence to come swiftly. ${ }^{37}$ Describing these desires as the "voice and consciousness" of the people, the author publically incorporated statehood into the nationalist conception of Lithuanian identity. The author also stipulated that an independent Lithuanian state required its capital to remain in Vilnius, implicitly alluding to the city's importance within the Lithuanian framework and foreshadowing the coming conflicts concerning it. ${ }^{38}$ These articles reflect the ever-growing agitation among Lithuanian leaders as the war dragged on, a sentiment that increasingly could be heard in all corners of Lithuania, at every level of society. While certain political groups maintained separate agendas, the general consensus continued to grow daily among the Lithuanian people, soon to culminate in their Declaration of Independence. ${ }^{39}$

\section{Long Distance Relationship: Émigré Advocacy as Nationalism}

While Lithuania struggled to navigate the hardships of war and negotiate their tenuous position between Russia and Germany, people and events outside the Baltic took an active role in shaping Lithuania's prospects. While scholars disagree as to which groups played the most vital roles in influencing the fledgling Lithuanian identity, expatriates, refugees, and others, particularly in the United

\footnotetext{
${ }^{34}$ Ibid., 3.

${ }^{35}$ Ibid., 3. While the article speaks in terms of revival, it is important to note that Lithuanians use this terminology throughout this process. While the case for revival certainly exists, this term is meant to justify the national movement as a continuation of the past, rather than the invention of new traditions and ideas, and therefore, more palatable to the international community.

36 "Mūsų siekiai" (Our Aspirations), Lietuvos Aidas, trans. Kristina Petruitytė, January 5, 1918, \#3(51), p.1. http://www.epaveldas.lt/vbspi/biRecord.do?biExemplarId=66492.

${ }^{37}$ Ibid., 1.

38 "Mūsų siekiai," 1.

${ }^{39}$ Kiaupa, 238.
} 
States rallied together on behalf of the Lithuanian people so effectively that their significance cannot be overemphasized. Alfred Senn highlights the intellectuals and students of Western Europe as the centre of the national movement until 1917, led by Juozas Gabrys and other members of Lithuania's expatriated intelligentsia. ${ }^{40}$ Tomas Balkelis, on the other hand, dismisses Senn's perspective as too narrow, following the exploits of a few well-known leaders at the expense of the masses. ${ }^{41}$ Instead, Balkelis credits the oft-ignored émigré population in Russia with the highest levels of political agitation concerning Lithuanian nationalism prior to the birth of the new state. Unfortunately, this group frequently found itself silenced by their precarious existence as refugees in the last years of the Russian Empire. ${ }^{42}$ Heated debates in St. Petersburg at this time may have heavily influenced the perspectives of their participants, but the refugees failed to establish any unified platform concerning their homeland. Moreover, they dared not publically declare themselves in favor of a wholly independent state while receiving food and other forms of aid from a Russian government still clinging to its hopes of restoring the Baltic region to its borderlands by the end of the war. ${ }^{43}$ While both Senn and Balkelis make excellent points concerning the nature and value of each camp of advocates, neither Eastern nor Western European refugee groups could single-handedly dictate the Lithuania debate and hope to succeed. A third segment of the Lithuanian population, LithuanianAmericans, pouring out their voices and resources on behalf of their homeland, unquestionably influenced the character of Lithuanian nationalism and proved vital in orchestrating the creation of a Lithuanian state. With their uniquely American flair, these efforts helped trigger relatively positive results where so many other national campaigns had failed (i.e. Czechoslovakia).

The Lithuanian Information Bureau underscores the significance of these populations in the development of Lithuanian national fervor and advocacy for a Lithuanian state. As Tomas Balkelis ironically points out, the first calls for full Lithuanian independence came not from Lithuania proper, but from a conference of émigrés in Bern, Switzerland in 1916. ${ }^{44}$ The conference itself stemmed from the rigorous efforts of an organization known as the Lithuanian

\footnotetext{
${ }^{40}$ Senn, Emergence, 23.

${ }^{41}$ Balkelis, Making of Modern Lithuania, 107.

${ }^{42}$ Ibid., 107-108.

${ }^{43}$ Balkelis, 108.

${ }^{44}$ Balkelis, Making of Modern Lithuania, 106.
} 
Information Bureau, a Paris-based group founded in 1911 under the leadership of exiled Lithuanian politician Juozas Gabrys. Designed to educate the rest of the world on the history, culture, and present circumstances in Lithuania, the Bureau published prolifically, distributing over fifty works in French (still the diplomatic language of Europe) that describe Lithuanian language, customs, and historical significance. ${ }^{45}$ Though they transferred operations to Switzerland as war swept into France, the Bureau continued working tirelessly to draw attention to a region otherwise overlooked in an international arena dominated by multi-ethnic empires. In response to these efforts, Lithuanian populations across the globe took up the cause of their homeland with a fervor that could not yet express itself in Lithuania proper.

Heavily concerned with the state of affairs in their war-torn homeland, Lithuanians in America kept a watchful eye on the region as the war unfolded. As early as September 1914, the Lithuanian immigrant community called a conference, gathering representatives from as many existing LithuanianAmerican organizations as possible to consider the war's implications for their homeland and the appropriate course of action. The delegates rallied to the Lithuanian cause, publishing resolutions concerning increased autonomy for Lithuania, while establishing a National Fund for their cause, and pledging to actively solicit the US government to aid in the protection of Lithuanian interests. ${ }^{46}$ To further this endeavor, the conference voted to establish a branch of the Lithuanian Information Bureau within the United States to assist in the publication and distribution of information to support their cause. Though this gathering highlighted a number of practical and ideological differences among the various organizations, it galvanized the émigré population into a flurry of activity, hoping to call attention to Lithuania's plight.

Perhaps the most vital and ongoing role filled by Lithuanian-Americans in the shaping Lithuanian identity lay in their thorough and persistent dissemination of information concerning their homeland and its aspirations. Their steady stream of publications over the course of the war focused intently on stories that provided background on the Lithuanian people or evidence with which to strengthen the Lithuanian cause. With titles like A Plea for the Lithuanians

\footnotetext{
${ }^{45}$ Kučas, 161.

${ }^{46}$ Antanas Kučas, Lithuanians in America, trans. by Joseph Boley, (Boston: Encyclopedia Lituanica, 1975), 143-148. Robertas Selenis, "Lithuanians in America: A Historical Sketch," Lituanus, Vol. 17, No.4, 1971.
} 
and Lithuanian Booster, journals and magazines sought to enlist the interest and assistance of as wide an audience as possible, whether that aid presented itself in military action, peace processes, agitation for independence, or any combination thereof. Under the guidance of the Lithuanian National Council, the Washington D. C.-based Information Bureau rallied the United States to the cause of independence, and counteracted any rival claims to the Lithuanian homeland. Thus Lithuanian-Americans rapidly became Lithuania's loudest and most prolific defendants. ${ }^{47}$

These calls for autonomy abounded within Lithuanian-American society, but the majority of Lithuanian émigrés initially focused their efforts on more feasible projects addressing more immediate needs caused by the war. To that end, the American Relief Fund for Lithuanian War Sufferers began collecting funds to alleviate the suffering within the Lithuanian population. Already developing into Lithuania's strongest advocates, Lithuanian-Americans flooded newspapers with articles calling attention to events along the Eastern Front. Many such articles point out that the German and Russian armies had swept through Lithuania six times by August 1916 in their struggle for dominance, but that international aid organizations had largely ignored the damage inflicted on the now-starving Lithuanian people. ${ }^{48}$ This ignorance stems at least in part from a widespread lack of understanding concerning the region and its people. One article blames the error on the fact that regions of Lithuania at this time found itself incorrectly labeled by military experts as Northern Poland, while Polish relief organizations felt they had little reason to concern themselves with Lithuanian refugees. ${ }^{49}$ Some Lithuanian-Americans found the misnomer highly offensive, as one letter to the editor indignantly reclaims these territories as distinctly Lithuanian, marked by a unique language and culture. ${ }^{50}$ Faced with such instances of ignorance, the Relief Fund doubled its efforts, even sending investigative teams into the Lithuanian war-zone to assess matters, and obtaining an audience with the Pope concerning the dire situation ${ }^{.1}$ This intensity of feeling in Lithuanian-American communities merely indicates a rapid growth of

${ }^{47}$ The Lithuanians in America 1651-1975: A Chronology and Factbook, edited by Algirdas M. Budreckis (New York: Oceana Publications, 1976), 22.

48 "Lithuania Swept by War Six Times," New York Times, Aug. 13, 1916, X6.

49 "Distress in Lithuania," 3.

${ }^{50}$ J. O. Sirvydas, "Silence Concerning Lithuania," New York Times, May 5, 1915.

51 "Lithuanian Swept by War Six Times." 
nationalist sentiments within the Lithuanian population abroad that massively contributed to the Lithuanian cause.

After months of urging, the Relief Fund and Lithuanian-Americans at large convinced Congress and President Wilson to declare November 1 as Lithuania Day, in which US citizens might "express their sympathy by contributing to the funds now being raised for the relief of Lithuanians in the war zone." 52 Jointly and independently, various Lithuanian-American societies raised hundreds of thousands of dollars dedicated to the Lithuanian cause over the course of the war. Even personal occasions like weddings became fundraising events, like one small Chicago wedding that raised \$13.25 for the Fund (\$296.5 in 2012). ${ }^{53}$ Some of these funds went directly to the front lines to ease the hardships of war, while the organizations dedicated various levels of funding to the fight for autonomy or independence, cultural education, and diplomatic endeavors. These numbers become significantly more impressive with the realization that the average Lithuanian-American family made a mere $\$ 638$ per year prior to the war $\left(\$ 14,397.87\right.$ in 2012)..$^{54}$ Nor did Lithuanian-Americans' giving end there; when the US finally entered the war in 1917, between 30,000 to 50,000 Lithuanian Americans rushed to fill the ranks of the military. ${ }^{55}$

Financial aid and military service certainly advanced Lithuanian national endeavors, but Lithuanian-Americans had still more to say concerning the Lithuanian state and national identity. Realizing that Polish and Russian representatives with their own agendas for the territory had already begun spreading their beliefs across Washington, Lithuanian-Americans saw an urgent need to counteract any claims that did not align with their own agenda for a future Lithuanian state. ${ }^{56}$ In the steady stream of articles aimed directly at US government agencies, politicians, and the press, the Information Bureau compiled an extensive body of evidence in favor of Lithuanian sovereignty that came to represent the general consensus of most Lithuanian-Americans and their organizations. ${ }^{57}$

52 Woodrow Wilson, "Proclamation of the President.," August 31, 1916, in Kunigas Jusaitis, The History of the Lithuanian Nation (Philadelphia: Lithuanian Catholic Truth Society, 1919).

53 "War Relief Contributions at Wedding," Naujienos, January 13, 1915, 3. http://flps.newberry. org/article/5423970_3_0360.

${ }^{54}$ Karol Wachtl, Polonja w Ameryce (Poles in America), Philadelphia, 1944, quoted in Kučas, 158.

${ }^{55}$ The Lithuanians in America 1651-1975, 22.

${ }^{56}$ Kučas, 162.

${ }^{57}$ Kučas, 162. 
A prime example of this advocacy arises in the "American Lithuanian's Declaration" that the Lithuanian National Council handed to President Wilson, the Pope's representatives, and European ambassadors in early 1917. In this text, Lithuanian-Americans briefly outlined Lithuania's history as a separate nation and powerful state in the fourteenth and fifteenth centuries, establishing Lithuania's historical legitimacy on the global stage. ${ }^{58}$ The text goes on to speak of Lithuania's unsubdued national sentiment and desire for independence as exemplified in peasant songs and literature, confirming that despite Russian occupation and repression, Lithuania lived on in cultural artifacts among intelligentsia and peasants alike. Moreover, the article emphasizes the Lithuanian's role in the Revolution of 1905, perhaps embellishing the truth in order to win the admiration and support of American and international leaders. ${ }^{59}$ Ultimately, the declaration implies that granting Lithuanians their freedom would greatly assist the international endeavor to stop the bloodshed, a claim that, while not necessarily grounded in reality, certainly appealed to the Allied Powers' desire to end the war in a tidy manner. The text reflects many tactics of LithuanianAmerican advocacy that would find themselves repeated continuously in the coming years, as well as a willingness to bluntly address even the highest levels of leadership on behalf of a future Lithuanian state. Publications like this one flooded the press and provide crucial insight into the evolution of Lithuanian national identity in the eyes of Lithuanian-Americans. Moreover, these works reiterate the vast extent to which Lithuanian-Americans weighed in on the affairs of their homeland as war raged onward and Lithuanians pressed closer to their goal of independence.

\section{Obstacles to Recognition: Fighting for Acceptance in the Post-War World.} When the Tarbya published its declaration of independence, the German occupation rendered the document ineffective in any practical sense. Lithuanians could neither form their own government, nor make their own decisions in the diplomatic arena, and daily life changed little. Despite this lack of tangible results, Lithuanian-Americans immediately jumped to the defense of the new state and began outlining their expectations for the direction this state should take.

\footnotetext{
${ }^{58}$ Lithuanian National Council, “American Lithuanians' Declaration,” 1917, in Kunigas Jusaitis, The History of the Lithuania Nation, (Philadelphia: The Lithuanian Catholic Truth Society, 1919), 151.

${ }^{59}$ Ibid., 152-153.
} 
A convention of Lithuanians met in New York City in March 1918, echoing the words of the Tarbya's declaration as they confirmed that Lithuania existed as a sovereign "ethnographic, cultural, economic, and political entity" based firmly upon President Wilson's declaration concerning self-determination. ${ }^{60}$ Although technically Lithuanian-Americans had no legal right to dictate the requirements of the Lithuanian state, the convention went on to outline various rights and freedoms that "citizen[s] of Lithuania [...] shall enjoy," as well as policies concerning the nationalization of resources and commercial enterprises, and the republican form of government to be established. ${ }^{61}$ On some level, it seems mildly absurd that an émigré population might dictate the formation of a new state, but the role played thus-far by the Lithuanian-American community gave them a significant amount of leverage. While the leaders and politicians in Lithuania certainly could have ignored these voices from across the sea, in reality, Lithuanian émigrés possessed a great deal more freedom at the time than Lithuanians still under the German Ober Ost. These politicians and activists owed and would continue to owe quite a debt to the work of the Lithuanian population abroad as they waited out the end of the war, trying to make their audacious declaration a reality. In the international arena moreover, these declarations proved absolutely necessary for any state that hoped to earn international recognition within the context of the war, reassuring all that they would subscribe to democratic principles and look out for the well-being of all their citizens so as to prevent future wars from occurring on such a horrendous scale. Such declarations from Lithuanian-Americans served to make the idea of an independent Lithuania as palatable as possible to the United States, which appeared to wield increasing amounts of influence over the course of the war and its eventual resolve.

As Lithuania's politicians balanced precariously between the German occupation and their assertion of independence, the Lithuanian National Council in Washington D. C. began publishing "Facts Supporting Her Claim for Reestablishment as an Independent Nation" to convince the world of the validity of Lithuania's declaration, and solicit the aid of the so-called Great Powers in this process. ${ }^{62}$ The pamphlet served as a template for many subsequent

${ }^{60}$ The Lithuanians in America, 96-97.

${ }^{61}$ Ibid., 97.

${ }^{62}$ Lithuania: Facts Supporting Her Claim for Reestablishment as an Independent Nation, ed. by J.J. Bielskis, (Washington D. C.: The Lithuanian National Council, 1918). 
documents, briefly outlining the territories that Lithuanians intended to include in their new state and reiterating their linguistic distinctions, before delving into a shortened version of Lithuanian history from the thirteenth century onward. Interestingly, the pamphlet refers to the outbreak of war in 1914 as an untimely interruption of a Lithuanian national revival and the people's efforts towards independence, despite more recent scholarship to the contrary ${ }^{63}$ Prior to the war, Lithuanian nationalism had not yet achieved a level of coherency needed to consider statehood, much less view it as an inevitable reality. In fact, most scholars concur that the war played a vital role in accelerating the development of national identity in Lithuania. In light of this contradiction, the Lithuanian National Council's claims reflect overconfidence at best, and utter delusion at worst, but this reflects just how fervent Lithuanian nationalism had become within the émigré population of the United States. After all the rallies, all the publications, and all their efforts on behalf of the homeland, Lithuanian-Americans genuinely believed that their brothers would have secured their liberty even sooner without the war. Present perspectives may discount such ideas, but the pamphlet's approach still appears logical as the words of a national movement justifying its claims for an independent state. If Lithuania had made its way to the brink of liberation prior to the war, then how could anyone deny them their freedom after much suffering and delay? Although the council could not have predicted it, the text also handily preempts many complaints that smaller national groups greedily demanded far more than they could reasonably claim. If Lithuania could prevent itself from falling into such categories, then the Great Powers (and subsequently the League of Nations) might treat their national agenda with more care and respect.

As World War One petered towards the armistice in 1918 and German power waned, Lithuanians finally began developing an independent state for themselves and those minorities that chose to remain under their jurisdiction. The tasks of formulating their new government and continuing to appeal for international recognition of their infant state consumed their efforts. Lithuanians all over the world had struggled and petitioned for this moment for years, but the end of the war brought unprecedented opportunities for Lithuanians to define themselves and their homeland. With this freedom, however, came the massive responsibility of outlining a Lithuanian identity that the majority of

${ }^{63}$ Lithuania: Facts, 37. 
the world both inside and outside Lithuania would also find acceptable. Faced with a seemingly insurmountable task, the Lithuanian leadership strove to form a government based on the principles of democracy that the new global leaders held as the standard (at least in Europe). As part of this process, the Tarbya established a provisional government headed by Augustinas Voldemaras as prime minister, and a Council and Cabinet of Ministers to serve as the executive branch until a Constituent Assembly could be called to hammer out the finer points of state. Moreover, Lithuania began sending out envoys to its nearest neighbors, and gathering delegations to attend the Paris Peace Conference, where they hoped to persuade the world to acknowledge their existence. As if to combine forces, delegations from the new Lithuanian government and from Lithuanian-Americans converged at the conference to convince the world of their legitimacy. While they failed to gain any direct acknowledgement, one paragraph of the resultant Treaty of Versailles did allow the provisional governments in all three of the Baltic States to take any necessary measures to defend against the spread of Bolshevism. ${ }^{64}$ This indirect sort of acquiescence, however, still denied Lithuania the official status of statehood, and restricted the forms of aid that other states could or would give.

Although Lithuanians may not have appreciated this struggle, the ongoing fight for recognition forced Lithuanians to really articulate their agenda, how they perceived themselves, and what they wanted as a long term political entity. Since much of Eastern Europe saw the end of the war as an opportunity to spring free of Russian dominion and German occupation in one fell swoop, the quest for recognition developed not just among Lithuanians and Lithuanian-Americans. In September, 1919, Estonians, Latvians, Lithuanians and Ukrainians in the United States banded together in order to present their cases jointly. In this congress, the four nationalities argued that their children had helped the US in their fight to end autocratic governments and oppression, and that they, as representatives of three million Americans, desired their adopted country to extend a hand of warmth and friendship to their beloved homelands. ${ }^{65}$ The joint congress reiterated the similarity of ideals between their homelands and the US, while emphasizing the United States' line that World

\footnotetext{
${ }^{64}$ Kučas, 172.

${ }^{65}$ The Case of the New Republics of Esthonia, Latvia, Lithuania, and Ukraine, presented at the First Congress of the League of Esthonians, Latvians, Lithuanians and Ukrainians of America, (New York, 1919), 7.
} 
War One had occurred so that these peoples too might enjoy the democracy and liberty that so embodied the war in American minds. ${ }^{66}$ This combined effort underscores that Lithuania by no means stood alone as a young nation begging for international blessings to progress with the formation of a new state. These fledgling movements profited greatly from such US-based alliances when addressing international leaders, either individually or as the League of Nations, despite the fact that such alliances did not often exist in the European sphere. While such efforts may have convinced other leaders however, it seems that in most cases, the United States refused to budge.

On September 25, 1919, Great Britain became the first of the Great Powers to recognize Lithuania as an independent state, while Lithuania's nearest neighbors soon followed suit. ${ }^{67}$ For Britain, recognition came out of the practicalities of the post-war environment. Fearing the spread of Bolshevism outward from Russias borders, Britain saw the entire Baltic region as a potential barrier to further Bolshevik expansion. By recognizing Lithuania, the British could assist in the struggle against the Bolsheviks and thus protect the rest of Europe from the fearful specter of Communism. ${ }^{68}$ While perhaps more utilitarian than springing from conviction, this decision dramatically benefited the Lithuanian national cause. British recognition ignited a wave of other recognitions for an independent Lithuania, ranging from France to Sweden and even Argentina. ${ }^{69}$ The United States, however, continued to deny the legitimacy of a Lithuanian state for a significantly longer period, much to the dismay of Lithuanians on both sides of the Atlantic.

\section{Obstacles Part II: Convincing the Americans}

Lithuanian efforts to obtain official American approval continued to construct and solidify the textures and appearances of the Lithuanian state and what it meant to be a Lithuanian, relying on a combination of history, ethnography, and constant comparisons of themselves and their new state with longstanding American principles and explicitly stated war aims. The Lithuanian Review, a publication of the Lithuanian Information Bureau, outlined "Three Reasons

\footnotetext{
${ }^{66}$ Ibid., 7.

${ }^{67}$ "Copy of Note Extending Recognition to Lithuania by Great Britain," in Lithuanian Recognition, (Washington D. C.: Lithuanian Information Bureau, 1921), 16.

${ }^{68}$ Kučas, 178-179.

${ }^{69}$ For official documentation, see Lithuanian Recognition, (Washington D. C.: Lithuanian Information Bureau, 1921), 16-24.
} 
why Americans should Recognize Lithuania” that help illustrate the developing Lithuanian identity. According to the article, the United States should recognize Lithuanian sovereignty first and foremost because it falls in line with "the declared American war aims of ethnic self-determination for racially distinct groups." ${ }^{70}$ The section firmly asserts Lithuania’s racial distinctness and chidingly reminds readers that American opinion aligned with Lithuanian desires and that ignoring racial differences in the Balkans helped spark the war in the first place. By bluntly reminding their adopted country that these issues played a role in dragging the world into war, Lithuanian-Americans cleverly hinted that recognition would help prevent future conflict and allow the US to return to its own affairs. Secondly, the article reminds Americans of their own struggle for statehood, recalling their contribution to that cause in the person of General Tadeusz Koscuiszko (despite Polish claims to the contrary), and favorably comparing American liberties to those sought by Lithuanians in the post-war world. ${ }^{71}$ How could the United States deny Lithuanians the right to their own state when all they wanted were the freedoms and traditions that the US had once fought so hard to gain and defended fiercely ever since? The article's third reason manipulates American and international desires to never experience another war like the one that had just torn Europe apart, claiming that an independent Lithuania would stand against Germany as it had already done and that such efforts more than amply justified recognizing Lithuanian independence.

Unfortunately for the Lithuanians, this last justification failed to hold up under any level of scrutiny within the international situation in 1919. In reality, Lithuania had collaborated closely with the Germans in the last years of the war as other options had failed them and the new state still found itself heavily dependent on Germany in the initial post-war era. As long as other powers refused to acknowledge Lithuania's existence, Germany became one of the few venues through which Lithuanians could voice their opinions in an international forum, and German troops remained in Lithuania long after the war's end. Moreover, international politics had shifted greatly with the rise of the Bolsheviks, transforming Russia into a greater source of anxiety than the heavily punished Germans. As long as the threat of socialism hung over Europe,

70 "Three Reasons Why America Should Recognize Lithuania," Lithuanian Review, edited by Rev. J. J. Kaulakis, (Washington D. C.: Lithuanian Information Bureau, 1919), 20.

71 "Three Reasons," 20. 
the United States in particular seemed willing to support Germany so long as it held back the Bolsheviks, while Lithuania mattered little either way. This error in calculation reveals that despite his fervor, the aforementioned article's author could not quite grasp the new international balance of power, particularly concerning Germany and Russia.

Advocates of Lithuanian recognition in the US repeatedly relied on American policies and historical traditions in order to persuade US officials to grant their blessing to the Lithuanian experiment of statehood. One memo pulls quotes from James Buchanan, Woodrow Wilson, and Secretary of State Lansing that remind US leaders of the long-standing US policy of support for self-determination. ${ }^{72}$ A 1921 letter to then-Secretary of State Bainbridge Colby, blames US policies, refusing to acknowledge the fall of the Russian Empire for the delay in recognition. ${ }^{73}$ As long as the US held out hope that the tsars would return, its diplomatic branch refused to consider any changes to Russia's former territories, a move that certain American lawyers, statesmen, and experts considered extremely counterproductive. As William McAdoo, Herbert Adams Gibbons, and Walter M. Chandler cautioned in their letter, doing nothing in hopes that the former Russian Empire would reemerge left non-Russian borderlands such as Lithuania vulnerable to the spread of Bolshevism, a move that certainly could not benefit the United States long term. ${ }^{74}$ These gentlemen also warned that tensions between the Poles and Lithuanians over Vilna and other border disputes might lead Europe into war again, a dismal prospect for anyone hoping that World War One had literally been the war to end all wars. The fact that the League of Nations refused to allow Lithuania to join due to the US attitude toward the young nation only fortified these fears, since this meant that no major power would actively interfere in the event of Polish-Lithuanian aggression. ${ }^{75}$ Lithuanian-Americans and their allies actively pointed out such problems in hopes of convincing the United States of what they considered a dire need for action concerning their homeland. They bombarded US officials

\footnotetext{
72 "Memorandum to the Secretary of State in Behalf of Recognition of Lithuanian Independence," Lithuanian Recognition, (Washington D. C.: Lithuanian Information Bureau, 1921), 6.

73 "Letter of McAdoo, Cotton and Franklin to Secretary of State Colby," Lithuanian Recognition, (Washington D. C.: Lithuanian Information Bureau, 1921), 2.

74 "Letter of McAdoo, Cotton and Franklin to Secretary of State Colby,"3-4.

75 "Memorandum to the Secretary of State in Behalf of Recognition of Lithuanian Independence,"
} $10-11$. 
with proof of other countries that had already granted recognition to Lithuania as if the sheer volume of these memos would convince them to change their minds. Another approach included a detailed analysis of Lithuania's economic status in which the author presented various statistics for education, agriculture, industry, and the financial sector, as if proving Lithuania's economic viability would convince the United States to actually recognize its independence. ${ }^{76}$

Even after the League of Nations admitted Lithuania as a member, the United States continued to stall, as if waiting would somehow force the issue to disappear. While one might speculate that America's Red Scare and rampant phobia of Bolshevism forced the United States to insist on the sovereignty of a dead Russian empire, a realistic analysis of the situation reveals very little in the way of logic that justifies US action or rather inaction in this situation. When Secretary of State Hughes finally announced US recognition for Lithuania on July 25, 1922, he provided no substantial reasons for his delay outside of the Russian factor, and seemed resigned only because so many other nations had already done so. With this announcement, Lithuania finally attained a measure of security in knowing that none of the Great Powers questioned their right to existence any longer. ${ }^{77}$

\section{On the Map: Defining and Defending Lithuania's Borders}

In striving to prove Lithuania's historical and cultural rights to the land in such a way that neither Russia, Germany, Poland, nor anyone else could contradict, Lithuanians on both sides of the Atlantic faced the enormous problem of drawing territorial boundaries that would prove acceptable to both the Lithuanian population and the greatest number of European states possible. In a Lithuania that had existed under foreign occupation for more than a century, borders had been drawn and redrawn according to the policies of the Russian Empire and the fortunes of war. Alfonsas Eidintas, Vytautas Žalys, and Alfred Erich Senn illustrate that when Lithuanians everywhere found themselves faced with the sudden potential to outline their own borders, they lacked any definite blueprint

76 “The Economic Basis for Lithuania’s Claim to Independence," Lithuanian Recognition, (Washington D. C.: Lithuanian Information Bureau, 1921), 28-34.

77 "The U. S. Secretary of State, Hughes, to the U. S. Commissioner in Riga, Young," July 25, 1922 in The USSR-German Aggression Against Lithuania, (New York: Robert Speller and Sons, Publishers, Inc, 1973), 85-86. 
from which to begin. ${ }^{78}$ In undertaking the design of a new state, Lithuanians struggled to choose between the lands once ruled by their ancestors, all the lands Lithuanians had ever inhabited, or lands where Lithuanians lived in the present. ${ }^{79}$ This choice between the historic and variations on the ethnographic became even further complicated by the reality that other states, as well as internal nationalities might dispute any of these claims. A somewhat vague and unhelpful answer to this problem came about when President Wilson agreed to form a committee for the sole purpose of investigating the Lithuanian question in May 1918. "'Ask for the most, but always have proof that it truly belongs to you," advised the committee's chairman, Harvard professor Frank A. Golder. ${ }^{80}$ Although Golder went on to detail certain regions and ethno-religious backgrounds that could logically be included, this statement underscores the complexity of the task facing the Lithuanians. Exactly where and how much land could they carve out of Europe to meet the needs of a Lithuanian state, while maintaining the legitimacy of those claims?

Even as Lithuanians wrestled with these questions, external forces began to impose their own interpretations upon the region, challenging not only specific aspects of the process, but the entire legitimacy of a Lithuanian state. Foremost of these challenges came from Bolshevik Russia, which despite being enveloped in its own civil war, increasingly desired to retain the borders of the former Russian Empire as its own. Almost immediately after the armistice took effect across Europe, the Bolsheviks reneged on the terms of the Treaty of Brest-Litovsk and launched a full scale invasion of the still army-less infant republic. Though some German troops remained in the region at the time, they and their Lithuanian counterparts proved unable to ward off the invasion, sending Lithuanian leaders fleeing the capital in order to preserve their young government. Local socialists welcomed this invasion with open arms, and in February 1919, the Bolsheviks set up their own government in Vilna under the jurisdiction of the Soviet Republic of Litbel, a quasi-state that combined both the names and territories of Lithuania and Belorussia. ${ }^{81}$ Meanwhile, most Lithuanians rallied to defend their republic, bolstered by high hopes and the

\footnotetext{
${ }^{78}$ Alfonsas Eidintas, Vytautas Žalys, and Alfred Erich Senn, Lithuania in European Politics: The Years of the First Republic, 1918-1940, (New York: St. Martin's Press, 1997), 2.

${ }^{79}$ Eidintas, Žalys, and Senn, 2.

${ }^{80}$ Frank A. Golder, quoted in Kučas, 162.

${ }^{81}$ Kiaupa, 245-246.
} 
new government's promises of land reform to a population dominated by peasants. ${ }^{82}$ A clever diplomatic move by Lithuania's new leaders, this promise ushered in droves of peasant volunteers, giving them a tangible reason to invest in the future of the young state and fight in its defense. By the summer of 1919, a combination of German, Lithuanian, and Polish armies had neutralized the government of Litbel, forcing the Soviets to negotiate peace. The treaty signed in July 1920 reestablished desirable Lithuanian borders (for the Lithuanians) and relinquished all Soviet claims on Lithuania's people or resources. ${ }^{83}$ Overstretched by civil war and a badly damaged economy, the Soviets proved unable to enforce their version of Lithuania upon the region, while their failure only seemed to validate the existence of a Lithuanian state and inject Lithuanian nationalism with even greater enthusiasm.

\section{The Vilna Conflict}

As the Lithuanians successfully fought off the Soviets and rogue German forces known as the Bermondtists, their long-standing conflicts with the Poles came to a head under the pressures of the two groups' diverging conceptions for the future of the region, and posed serious setbacks to Lithuanian nationalism and its definitions. As previously discussed, Russian policies had fostered opposing nationalisms in the region as a means of keeping Polish ambitions in check, but neither people agreed to Russian perceptions of nationality or territory. The same issues that had undermined the 1863 Uprising only grew more pressing as Polish troops under the command of Józef Piłsudski crossed into Lithuanian lands under the pretext of fighting off the Soviets. The Russo-Polish War, supported by Western powers as a challenge to the spread of Bolshevism, bought Lithuanians time to muster their own armies against the Soviets, but also nullified many stipulations of the Soviet-Lithuanian peace treaty before the ink had even dried. The Poles, not the Lithuanians, forced the Soviets from Vilna before settling in, reclaiming the city as their historic right, with the intention of using it as a jumping off point to reclaim territory that they perceived as rightfully Polish. The ensuing conflict sheds light on the processes through which both groups presented their definitions of Lithuania and how Lithuanians dealt with

\footnotetext{
${ }^{82}$ Eidintas, Žalys, and Senn, 36-37.

83 "Treaty of Peace between Lithuania and the Russian Socialist Federal Soviet Republic," July 12, 1920, in The USSR-German Aggression Against Lithuania, (New York: Robert Speller and Sons, Publishers, Inc, 1973), 68-81.
} 
the these developments in the international arena.

Incensed over the loss of their capital, but militarily too weak to launch a counterattack, Lithuanians' vocal complaints dragged the League of Nations into the issue, forcing both parties to defend their claims to the city. To this end, the Lithuanian Delegation published a book concerning the "Lithuanian-Polish Dispute" complete with maps, drafts of protocols and agreements between the two parties, presenting the same historical narrative used during the independence and recognition debates. While initially factual, the documents quickly escalated to accusations of carefully planned deception on the part of the Poles. One section blasts the Poles for negotiating a peace agreement in 1920 only to move troops into Vilna a mere two days later. ${ }^{84}$ Another section claims that the League of Nations only involved itself in the issue after Polish leaders falsely accused the Lithuanians of cooperating with the Bolsheviks and instigating the aggression between the two peoples. ${ }^{85}$ In reality, Lithuanians lacked solid factual support for their claims to the city, but Poland's blatant dishonesty and naked aggression in war-weary Europe pushed the League to protect Lithuania from further incursions. To this end, the League established a new border between Poland and Lithuania called the Curzon Line, which Piłsudski promptly defied by moving his troops into territory that the League had just explicitly recognized as Lithuanian. Unfortunately for Lithuanians, the League preferred to preserve more widespread peace than try to physically enforce their decisions and risk another massive war.

Once again, Lithuanian-Americans led the way in defending their homeland's burgeoning identity, going to great lengths to persuade their new country to stand against Polish aggression. In the Lithuanian National Council's pamphlet Lithuania Against Poland: Appeal for Justice, they couched their requests in language both flattering and familiar to the United States, drawing subtle parallels between Lithuania's situation and US history while relying on lofty ideals to which they believe the US has long subscribed. The pamphlet established Lithuania as the underdog in the situation, set upon by the "numerically stronger power" of Polish forces, and favorably compared Lithuania to the United States' own early history. ${ }^{86}$ The authors further relied on US sympathies

${ }^{84}$ Lithuanian Delegation, The Lithuanian-Polish Dispute, (London: Eyre and Spottiswoode, Ltd., 1921), 9.

${ }^{85}$ Ibid., 16-17.

${ }^{86}$ Executive Committee of the Lithuanian National Councils, Lithuania Against Poland: An Appeal for Justice, (Washington D.C.: Lithuanian National Councils, 1919), 1. 
when they reminded the president that they had only fled Lithuania to escape Russian despotism, now replaced by Polish despotism in their minds. Given the US entanglement in its own Red Scare at the time, they tactfully reminded the US government that Lithuanian had taken up arms against Bolshevik forces, thus creating a sense of political solidarity between the two states and strengthening their plea for aid. Moreover, they expressed their appeal in terms of what "American citizens believe," implying that their requests stem from the sense of justice instilled in them by their ties to the United States. ${ }^{87}$ They claimed that a US failure to get involved would constitute a failure to live up to its own principles of justice and fair play. Ignoring the fact that the US had neglected to even acknowledge Lithuanian sovereignty almost two years after they declared independence, Lithuanian Americans felt that their new nation had a moral obligation to come to the aid of their homeland and had no qualms about saying so.

The Poles, however, did not merely entrench themselves within the disputed capital and dare Lithuania to come unseat them. They too compiled evidence to justify their actions, often directly contradicting the Lithuanian account. A Polish historical journal compiled its own collection of articles geared toward what it terms "The Question of Wilno." 88 The first article traces Polish influence within Lithuanian culture, from religion, literature, language, and the nobility. Its author claims that Lithuanians owe the Poles for Catholicism, for the educated members of its population, and a plethora of cultural developments, thereby concluding that all of Lithuania should fall under Polish jurisdiction. The second article, however, directly engages the questions surrounding the city of Vilna, claimed by Lithuania as its historic capital, and by Poland as a vital cultural center. Reciting the same tale of the Lithuanian-Polish Union used by Lithuanians to field their complaints, their rendition's subtle changes transform the same narrative into a fairly convincing case on behalf of the Poles. Where Lithuanians claim strict distinctions between their people and the Poles, the Polish account finds Russian nationalization policies to blame for the lessening of Polish influence by death, imprisonment, or deportation. ${ }^{89}$ Moreover, it cites the German census to claim that Poles indeed held a majority within the limits

\footnotetext{
${ }^{87}$ Ibid., 1.

${ }^{88}$ Poland and Lithuania: The Question of Wilno, edited by the Society "Straż Kresowa," (Warsaw: IMPR Galewski and Dau, 1921).

${ }^{89}$ Ibid., 20.
} 
of Vilna. ${ }^{90}$ Such contradictory narratives coming from both parties called into question both versions of history, while making it exceedingly problematic for the League to act decisively on the matter.

As the League of Nations turned their attention to larger concerns and the Poles settled more permanently into Vilna, everyone but the Lithuanians accepted the de facto situation. They never once relinquished their claims to the city, and vocalized their grievances long after the matter had dropped from the international scene. The simplest explanation for this lies in significance of the capital city to national identity, and by extension, Vilna's significance to the Lithuanian narrative. Capital cities often represent a nation and its ideals, while also standing as a center of government and culture. Much like the burning of Washington D.C. in the War of 1812, the loss of Vilna struck a heavy blow to Lithuanian morale, perhaps all the heavier for its richer history. The city, from which their forefathers had ruled what had formerly been the largest contiguous empire in Europe, appeared time after time in the Lithuanian narrative-as the home of the great Duke Gediminas, the place where Lithuanians were first baptized into Christianity, and where educated nationalists had moved to share ideas and foment on behalf of a Lithuanian nation. ${ }^{91}$ Despite its relatively small Lithuanian population, Vilna represented the heart and soul of the Lithuanian nation. The Lithuanians could not forgive the Poles for snatching Vilna from their grasp; indeed, their anger over the lost city and its surrounding territory kept them locked in a state of war with Poland until 1938.

From their precarious and less-recognized position, however, Lithuanian leaders lacked the manpower and international support to take the city back by force, so it remained part of Poland until the Second World War. ${ }^{92}$ The conflict, however, helped invest Lithuanians on both sides of the Atlantic in the fate of their homeland. Although a setback in the Lithuanian narrative, the loss of Vilna only solidified the nation's borders in the collective Lithuanian imagination, borders that many hoped to one day restore even as they began addressing more immediate problems. It strengthened ties between Lithuanian-Americans and Lithuania so much that many returned to Lithuania-to raise families, start businesses, and otherwise rebuild the region-while others dedicated their efforts to travelling between the two communities and building up strong

\footnotetext{
${ }^{90}$ Ibid., 21.

${ }^{91}$ The Vilna Problem, (London: Lithuanian Information Bureau, 1921), 3.

${ }^{92}$ Senn, The Great Powers, 55-56.
} 
connections. Thus the Vilna Conflict, though a negative event in the process of outlining a Lithuanian nation-state, bolstered Lithuanian national identity in a way the Poles could not have foreseen. The Soviet Union quasi-restored such imaginings, along with Vilna, after the Second World War, while the second Lithuanian Republic solidified them in the early 1990's.

\section{The Memel Question}

A more successful attempt by the Lithuanians to dictate the limits of their identity arose from their fight for the port city of Memel (present day Klaipeda) and the surrounding territory known as the Memel strip. Although the territory contained a significant population of Lithuanians, the German administration had placed the region within the jurisdiction of Lithuania Minor, the smaller, Prussian-ruled entity until the end of the war. Unlike Vilna, whose significance remained purely nostalgic in even Lithuanian minds, Memel held the promise of prosperity for the young nation. Lacking any major port cities, Lithuanian leaders had entered into discussions with the Germans concerning Memel as early as $1916 .{ }^{93}$ By war's end, Germany, and even Poland had, for various reasons, agreed to turn over the district to the Lithuanians. Despite this, the international community turned the territory over to Allied administration, with plans to internationalize the city and grant Allied Powers a foothold in an otherwise removed Eastern Europe. ${ }^{94}$ Lithuanians objected to handing Memel over to the French and passed a resolution to join all of Lithuania Minor (including the area surrounding Konigsberg), with the Lithuanian state. Adding to the confusion, the territory's population divided almost evenly into Germans and Lithuanians, who worried about Lithuania's economic prospects and being cut off from Germany.

1922 found Lithuania caught in an untenable position concerning Memel. Hoping to settle the region and guard against German and Russian ambitions, the British offered to give Memel to Lithuania along with de jure recognition and economic aid. In return, they expected Lithuanians to surrender Vilna to the Poles and let the matter drop. ${ }^{95}$ As Vytautas Žalys points out, however, the

\footnotetext{
${ }^{93}$ Kiaupa, 255.

${ }^{44}$ The Question of Memel, (London: Lithuanian Information Bureau, 1924), 7. Senn, Emergence of Modern Lithuania, 141. Kiaupa, 255.

${ }^{95}$ Alfonsas Eidintas, Vytautas Žalys, and Alfred Erich Senn, Lithuania in European Politics: The Years of the First Republic, 1918-1940, (New York: St. Martin's Press, 1997), 89.
} 
Lithuanian government could not bend on the Vilna issue without angering the Lithuanian people, citing an assassination attempt of an official who had suggested negotiations with Poland previously. ${ }^{96}$ Unwilling to let the region slip from their grasp, and spurred on by the occupation of Vilna, Lithuanian leaders organized an uprising dominated by Memel Lithuanians, and seized the district in December of 1922.

The Allied Powers objected strongly to such flagrant aggression, and quickly blockaded the harbor to force the Lithuanians to back down. In the face of the strong Allied response, the Lithuanians had no choice but to remove their troops, but only with the promise of a renewed discussion over the fate of the territory. Throughout the ensuing, yearlong diplomatic impasse, the Lithuanian Information Bureau continued to play a vital role, gathering and publishing correspondence that contextualized the issue and provided favorable evidence supporting Lithuania's claims and actions. In one such volume, the Bureau claimed that Memel territory possessed a significantly higher Lithuanian population than the Germans claimed, that the port served as a vital aspect of Lithuania's economic viability, and that Memel also needed Lithuanian commerce to survive. ${ }^{97}$ The Bureau also includes documents from Prussian Lithuanians in the district warning that Memel would be far too small to form an economically viable free state and the people of the territory preferred a union with Lithuania. ${ }^{98}$

The Allied Powers, predominately Britain, France, Italy, Japan, and the United States, proved much more flexible concerning Memel than the League of Nations had with Poland, especially since many believed that giving Lithuania Memel would make up for the as yet unresolved issue of Vilna. Even so, ironing out an agreement that both parties deemed acceptable proved exceedingly difficult. The Lithuanian Information Bureau emphasizes the difficulties of this process by displaying the proposed versions of the convention side by side. The Lithuanian draft of the agreement rewrote more than half its articles, making changes down to the smallest, seemingly insignificant details and phrasings. ${ }^{99}$ While even the smallest changes met with disapproval from the Allied Powers, the Lithuanians clung stubbornly to the port city as rightfully their own, fighting

\footnotetext{
${ }^{96}$ Ibid., 89.

${ }^{97}$ Question of Memel, 15, 17.

98 "Representations of Memel Delegations," The Question of Memel, 18-25.

99 The Memel Convention, (London: Lithuanian Information Bureau), 1923..
} 
tooth and nail for as many of their stipulations concerning the composition and jurisdiction of the region as possible. ${ }^{100}$

The Lithuanians' aggressive behavior, while seemingly abrupt and dramatic, pointedly reflects Lithuanian leaders' chagrin over their failure to recover Vilna, and their stubborn refusal to lose another inch of perceived Lithuanian ground. After two years of futilely trying to unseat the Polish presence, Lithuanians had no intention of letting another region, one more economically vital at that, slip from their grasp. The seizure of Memel reflects a Lithuanian adaptability to the challenges confronting their chosen narrative. Lithuanian leaders, already precariously balanced at the head of the new state, and under fire for the loss of Vilna, could not afford another failure of this nature if they wished to maintain the people's faith in their leadership, an urgency testified to by their sudden shift in tactics. While they had observed acceptable protocols with Vilna, and clearly failed, Lithuanians hoped that more decisive action would force the Allies to accept Lithuania's version, as it had with Poland and Vilna. ${ }^{101}$ Indeed, this route proved much more successful in obtaining the Lithuanians' desired results. After a year of deliberations, the 1924 Memel Convention officially recognized the region as part of the Lithuanian State. Following another four years of negotiations with Germany over the exact boundaries, Lithuania's borders remained intact, encompassing Memel, lacking Vilna and the easternmost portions of the desired territory, until the next world war rearranged Europe's borders once again.

\section{Final Thoughts}

In his book, Imagined Communities, Benedict Anderson defines a nation as an imagined political entity based on a perceived "deep, horizontal comradeship" between its members. ${ }^{102}$ For Lithuania, this comradeship evolved slowly, from a mere juxtaposition of language and geography to covert groups of disgruntled intellectuals, and eventually, to a Lithuanian Republic. At every step of this development, Lithuanians struggled to define themselves and gain recognition as a unique society and culture, while competing narratives thoroughly challenged them to defend these conceptions both intellectually and militarily. The First World War brought unprecedented opportunities to imagine a sovereign

\footnotetext{
${ }^{100}$ Poincaré, "Note," The Memel Convention, 28.

${ }^{101}$ Kiaupa, 256.

${ }^{102}$ Benedict Anderson, Imagined Communities, (London: Verso, 2006), 6-7.
} 
Lithuanian identity, bolstered by western promises for self-determination for all peoples. Meanwhile, the Lithuanian Declaration of Independence necessitated a firm, vocal defense of this identity in the international arena, a process that invested Lithuanians near and far in promoting the welfare of their new national identity and its associated state.

More importantly, these processes reveal an abundance of ways in which national identity is not only forged over imagined ties between community members as Anderson proposes, but also through external factors and challenges not inherently found within that community. Polish, Russian, and German antagonisms following independence forced Lithuanians to defend a still-forming identity, adapting words and weapons to suit their needs with equal vigor and enthusiasm. Urgently needing to articulate the essences of Lithuanian identity and justify their claims to the Entente and the League of Nations, Lithuanians vocalized those things that they perceived as most important in defining what made someone Lithuanian, and just where Lithuania referred to. The debt owed to Lithuanian-Americans cannot be overstated, both in the manner in which they besieged the U. S. government with pleas and proposals, and in their efforts to fund refugee aid and finance the nascent state. These factors forced Lithuanians to reimagine their history and their nation in ways and on a scale that no prior experience had required of them. Although the first Lithuanian Republic lasted a mere twenty-two years, the Lithuanian identity went on to survive another world war and nearly fifty years of Soviet occupation and deportation. It served as the foundation for the longest standing resistance movement against the Soviets after World War Two, and again when Lithuanians began to openly question the long-standing Soviet hegemony in 1990-91. Within a region of previously ambiguous identities, Lithuanians rallied to form a lasting identity based on real and imagined history and culture. In a fascinating study on the formation of national identity, the Lithuanian narrative reiterates the power of Anderson's imagined communities in shaping the nation and its identity, but also raises questions of exactly how such communities form and what external factors must also be taken into account. 
Anderson, Benedict. Imagined Communities. London: Verso, 2006.

"Atsiminimai ir ịspūdžiai iš Didžiojo Vilniaus Seimos." (Remembrances and Impressions of The Great Seimas of Vilnius). Lietuvos Aidas. Translated by Kristina Petruitytè. January 1, 1918, \#1. 49. http://www.epaveldas.lt/vbspi/biRecord. do?biExemplarId=66475.

Balkelis, Tomas. The Making of Modern Lithuania. London: Routledge, 2009.

The Case of the New Republics of Esthonia, Latvia, Lithuania, and Ukraine, presented at the First Congress of the League of Esthonians, Latvians, Lithuanians and Ukrainians of America. New York, 1919.

“Copy of Note Extending Recognition to Lithuania by Great Britain.” In Lithuanian Recognition. Washington D. C.: Lithuanian Information Bureau, 1921.

“Distress in Lithuania.” New York Times, Aug 12, 1915, 3.

“The Economic Basis for Lithuania’s Claim to Independence." In Lithuanian Recognition. Washington D. C.: Lithuanian Information Bureau, 1921. 28-34.

Eidintas, Alfonsas, Vytautas Žalys, and Alfred Erich Senn. Lithuania in European Politics: The Years of the First Republic, 1918-1940. New York: St. Martin's Press, 1997.

Executive Committee of the Lithuanian National Councils. Lithuania Against Poland: An Appeal for Justice. Washington D. C: Lithuanian National Councils, 1919.

Hiden, John, and Patrick Salmon. The Baltic Nations and Europe: Estonia, Latvia, and Lithuania in the Twentieth Century. London: Longman, 1991.

Jusaitis, Kunigas Antanas. The History of the Lithuanian Nation and its Present National Aspirations. Philadelphia: The Lithuanian Catholic Truth Society, 1919.

Kiaupa, Zigmantas. The History of Lithuania. Baltos Lankos, 2004.

Kučas, Antanas. Lithuanians in America. Translated by Joseph Boley. Boston: Encyclopedia Lituanica, 1975. 
"Letter of McAdoo, Cotton and Franklin to Secretary of State Colby." In Lithuanian Recognition. Washington D. C.: Lithuanian Information Bureau, 1921. 2.

Lietvos Tarbya. "Lietuvos Nepriklausomybès Aktas" in "Historical Lithuania." Vilnews. com. last modified 14 February 2012. http://vilnews.com/?cat=11.

"Lithuania and Poland," Lithuanian Review. Edited by Rev. J. J. Kaulakis. Washington D. C.: Lithuanian Information Bureau, 1918. 3-14

Lithuania: Facts Supporting Her Claim for Reestablishment as an Independent Nation. Edited by Bielskis, J. J.. Washington D. C.: The Lithuanian National Council, 1918.

“Lithuania Swept by War Six Times.” New York Times. Aug. 13, 1916. X6.

Lithuanian Information Bureau, The Memel Convention: Correspondence Between the Conference of Ambassadors and the Lithuanian Government. London: Eyre and Spottiswood, Ltd., 1923.

Lithuanian Information Bureau. The Vilna Problem. London: Lithuanian Information Bureau, 1922.

Lithuanian Ministry for Foreign Affairs. The Question of Memel. London: Eyre and Spottiswood, Ltd., 1924.

Lithuanian National Council. “American Lithuanians' Declaration.” 1917. In Jusaitis, Kunigas. The History of the Lithuania Nation. Philadelphia: The Lithuanian Catholic Truth Society, 1919.151.

The Lithuanian-Polish Dispute. London: Eyre and Spottiswoode, Ltd., 1921.

The Lithuanians in America 1651-1975: A Chronology and Factbook. Edited by Algirdas M. Budreckis. New York: Oceana Publications, 1976.

McAdoo, William, Herbert Adams Gibbons, and Walter M. Chandler. Lithuanian Recognition. Washington D. C.: Lithuanian Information Bureau, 1921.

"Memorandum to the Secretary of State in Behalf of Recognition of Lithuanian Independence," Lithuanian Recognition. Washington D. C.: Lithuanian Information Bureau, 1921. 6.

"Mūsų siekiai" (Our Aspirations)/ Lietuvos Aidas. Translated by Kristina Petruitytė. January 5, 1918, \#3(51). http://www.epaveldas.lt/vbspi/biRecord.do?biExemplarId=66492. 
Norus, T. and Jonas Žilius. Lithuania's Case for Independence. Washington D.C.: B. F. Johnson, Publishers, Inc., 1918.

Page, Stanley W. The Formation of the Baltic States; a Study of the Effects of Great Power Politics upon the Emergence of Lithuania, Latvia, and Estonia. Cambridge: Harvard University Press, 1959.

Poland and Lithuania: The Question of Wilno. Edited by the Society "Straż Kresowa." Warsaw: IMPR Galewski and Dau, 1921.

Selenis, Robertas. "Lithuanians in America: A Historical Sketch.” Lituanus. Vol. 17, No.4, 1971.

Senn, Alfred Erich. The Great Powers, Lithuania, and the Vilna Question: 1920-1928. Leiden: E.J. Brill, 1966.

Senn, Alfred Erich. The Emergence of Modern Lithuania. New York: Columbia University Press, 1959.

Sirvydas , J. O. “Silence Concerning Lithuania.” New York Times. May 5, 1915.

“Three Reasons why America should Recognize Lithuania." Lithuanian Review. Edited by Rev. J. J. Kaulakis. Washington D. C.: Lithuanian Information Bureau, 1919. 20

"Treaty of Peace between Lithuania and the Russian Socialist Federal Soviet Republic." July 12, 1920. The USSR-German Aggression Against Lithuania. New York: Robert Speller and Sons, Publishers, Inc, 1973. 68-81.

“The U. S. Secretary of State, Hughes, to the U. S. Commissioner in Riga, Young." July 25, 1922. The USSR-German Aggression Against Lithuania. New York: Robert Speller and Sons, Publishers, Inc, 1973. 85-86.

The Vilna Problem: With Five Maps. London: Lithuanian Information Bureau, 1921.

Wachtl, Karol. Polonja $w$ Ameryce (Poles in America). Philadelphia, 1944. Quoted in Kučas, 158.

“War Relief Contributions at Wedding." Naujienos. January 13, 1915. http://flps.newberry. org/article/5423970_3_0360.

Wilson, Woodrow. "Proclamation of the President." August 31, 1916. In Kunigas Jusaitis, The History of the Lithuanian Nation. Philadelphia: Lithuanian Catholic Truth Society, 1919. 